\title{
The Traditional Concept Umunthu as entangled in a Malawian Dance Teacher's Educational Practice
}

\author{
Sunniva Skjøstad Hovde \\ NTNU Norwegian University of Science and Technology
}

\begin{abstract}
Dance pedagogies globally are theoretically and often practically based on Western pedagogies. It appears that dance pedagogies deriving from African perspectives have had little visibility in African institutions and in institutions elsewhere. This article outlines some of the pedagogical dance practices and philosophies in Malawi, Southern Africa, expressed by John Duma, a merited dance teacher at Music Crossroads Malawi. His emphasis is on love, respect and self-confidence as a practical part of dancing, and achieving a balance between tribal-modern-urban-traditional-western perspectives in the community. The pedagogical perspectives are discussed as part of the Malawian concept uMunthu in an analysis of the entanglements of these different interests. The material is gathered through extensive ethnographic fieldwork over 4 years, including one formal interview. The material is analysed through diffractive analysis and post-qualitative theories.
\end{abstract}

Keywords: Arts education; traditional dance; Malawi; post-qualitative theory; decolonization.

\section{Sammendrag}

Dansepedagogikk er, globalt sett, både teoretisk og praktisk ofte basert på vestlig pedagogikk. Det ser ut som at dansepedagogikk fra afrikanske perspektiver har vært lite brukt i både afrikanske og andre utdanningsinstitusjoner. Denne artikkelen tar for seg noen av de pedagogiske og filosofiske praksisene i dansepedagogikk knyttet til tradisjonell dans i Malawi, gjennom John Duma's perspektiver. Han er en meritert danselærer ved Music Crossroads Malawi, Lilongwe. Hans vekt på kjærlighet/omtanke, respekt og selvtillit som praktiske deler av dans, og balanse mellom moderne-kulturelle-urbane-tradisjonelle-vestlige perspektiver i lokalsamfunnet. De pedagogiske perspektivene diskuteres som en del av det malawiske/afrikanske konseptet uMunthu, gjennom en entanglement-analyse av ulike interesser i lokalsamfunnet. Materialet er samlet gjennom 4 år med etnografisk arbeid, inkludert et formelt intervju. Materialet analyseres gjennom diffraktiv analyse og post-kvalitative teorier.

Nøkkelord: Kunstfagdidaktikk; tradisjonell dans; Malawi; post-kvalitative teorier; dekoloni-alisering.

Recieved: July, 2018; Accepted: February, 2019; Publisehed: September, 2019

Correspondence: Sunninva Skjøstad Hovde, epost: sunnivahovde@gmail.com

(C) 2019 S. S. Hovde.This is an Open Access article distributed under the terms of the Creative Commons Attribution 4.0 International License (https://creativecommons.org/licenses/by-nc/4.0/), allowing third parties to copy and redistribute the material in any medium or format and to remix, transform, and build upon the material for any purpose, even commercially, provided the original work is properly cited and states its license.

Citation: S. S. Hovde. "The Traditional Concept Umunthu as entangled in a Malawian Dance Teacher's Educational

Practice». Fournal for Research in Arts and Sports Education, Special Issue: "Community Arts/Arts Education»Vol. 3(1), 2019, pp. 101-117. http://dx.doi.org/10.23865/jased.v3.1326 
Dance is the life of a person's daily life today. If you wake up and cry, you'll make a dance. When you enter a part of your life, your dance may be Chisamba.Vimbuza is there to help you to heal. When there's a funeral we will dance Gule Wamkulo. That is the dance of a person of today. The life of today.

This is a fragment from an interview with John Duma, a significant contributor to the Malawian traditional dance scene for many years. Duma was a member of the Malawian National Dance Troupe when he was young; he then had his own dance troupe and he now teaches traditional dance at the music school Music Crossroads Malawi (MCM), a cultural institution in Lilongwe. Duma has contributed strongly to the traditional dance troupe Hear Us Children, consisting of 103 young dancers between 8 and 18 years old. They have become one of the most popular dance troupes in Malawi, and they have travelled many times to Europe, South America and inside the African continent.

With which terms, artistic and pedagogical concepts does he, within his tradition, teach someone to dance "the dance of a person of today", I wonder. In this article I pose the following research question:

With which terms, artistic and pedagogical, does John Duma express the educational entanglements in the teaching of traditional dance in Hear Us Children, and how is uMunthu a part of this?

Through investigating this research question, my aim is to allow Duma's perspectives on dance, music, sociality and cultural advocacy to contribute to the discourse on specific educational perspectives within African dances, as well as to contribute to research on Malawian dance and music, a very small subject in the academic field. Duma is significant as research participant as he is the only one training a group of young dancers in an urban environment in Malawi within the traditional expressions. Duma has read the article, discussed it with me, and I have asked him to clarify some things unclear to me while analysing. He expressed a wish to be named, and it has been clarified with Mr. Mfune at Music Crossroads Malawi. The study is approved by the Norwegian Centre for Research Data (NSD).

\section{Traditional Malawian dance pedagogies in a rapidly urbanizing environment}

Traditional Malawian dance and music are under pressure, as traditional expressions are not highly valued as a potential occupation: They tend to be difficult to make a living from in modern society, and they are connected to a life system associated with little education, little technology and traditional values and ways of living: a rural traditional knowledge system. There is a common understanding in Malawian society that anything Malawian has low status, while something European, American, South-African or Nigerian is of better quality, even though traditions are important for many Malawians, and the connection to the village (where your family comes 
from) has typically been important. The devaluation of local, regional and national symbols has also been fed by the development business, global colourism (white skin is more beautiful than dark skin), the lack of access to affordable technology and a lack of urban identity. Within these dynamics, Duma and Music Crossroads Malawi have trained young people in traditional dance, in an urban area.

Alfdaniels Mabingo (2015) is a dance researcher in a Ugandan context. He points out that even though the pedagogy in Ugandan traditional dance practice is not formal, it does exist. His outline of pedagogical points has many similarities with Duma's pedagogical perspectives: interactive dialogue and participatory learning, music as a teaching aid, storytelling as dance instruction, native terminology and the use of children's games to prepare the learner.

\section{uMunthu at the core of Malawian arts-educational context}

This inquiry focuses on the arts-educational perspectives that Duma emphasises as the core of his work. These perspectives are deeply embedded within Malawian culture, practices and concepts of life, uMunthu being a very important part of this. As such, Duma's perspectives are partofindigenous knowledge systems. Throughout the analysis, I consider how uMunthu is part of the pedagogical perspectives, how dance education contributes performatively to the concept of uMunthu, and with which terms, artistic and pedagogical, this teaching tradition teaches someone to dance "the dance of a person of today".

uMunthu (or uMuntu) is a sister concept of uBuntu, which might be better known because it came to the world's attention in the post-genocide healing of Rwandan society, and through Bishop Tutu as a tool of healing the deep wounds and segregation of South African society, post-apartheid. In Malawi, the concept uMu$\mathrm{nthu}$ is explained in the official language, chicherva through a proverb: "kali kokha nkanyama, tili awiri ntiwanthu". This means: "when you are on your own you are as good as an animal of the wild; when there are two of you, you create a community". The concept appears in Sub-Saharan Africa in many versions, and has been treated in research on environmental issues (Mfutso-Bengo \& Masiye, 2011; Kayira, 2015), conflict resolution (Akinola \& Uzodike, 2018), local knowledge (Tutu, 2010; Schreiber \& Tomm-Bonde, 2015) and development theory (Hoffmann \& Metz, 2017; Matthews, 2017) or philosophy (Murove, 2012). The philosopher Munyaradzi Felix Murove states that "a human being as a relational being does challenge the contemporary individualistic and self-interested understanding" and "humanness is our existential precondition of our bondedness with others" (Murove, 2012, p. 37). In the local community in Lilongwe, Area 23, no one talks about uMunthu, as it is the thread that society is woven from. If asked about uMunthu, the people I know connect the concept to humanity, having self-respect, showing compassion, and respecting the community and its elders, as well as being part of a community bigger than yourself. 


\section{Traditional dance}

Throughout the article I use the term "traditional" about the dances performed and rehearsed. "Traditional" here is to be understood as music, dance and songs, as well as stories deriving from different tribes in Malawi, as musicologist Austin Emielu uses the term when discussing tradition and modern music/dance in West Africa (Emielu, 2018), even though these will sometimes be shared between tribes and the same expressions can be found in different languages but with the same content. The most dominant tribe in Malawi is chewa, but the traditions of big tribes like tumbuka, yao and ngoni are also strong. The dance troupe Hear Us Children is not focused on one specific tribe, but rather on a spectrum of traditions within Malawi. Emielu (2018) points out that the concepts of popular and traditional music in an African context are artificial and do not represent the local perception of the expressions. These terms are still in use, even though Duma uses the term traditional and modern ${ }^{1}$, but they should not be understood as exclusive as they might be used in a European context, where the categorization comes from and where the traditions have developed differently than in African contexts (Emielu, 2018).

\section{Area 23, Lilongwe and Music Crossroads}

Area 23 of Lilongwe, one of the areas on the border of the city, is the home of about 650000 people (United Nations, n.d.). In this area, the Malawian branch of Music Crossroads ${ }^{2}$ can be found, a non-profit organisation, which uses the power of music education, professional training, live performances and the promotion of young talent to develop music education and the music industry in the southern African region. The impact of the institution locally is immense, and a lagre number of young musicians use this institution in Area 23.

\section{Methodological and ethical perspectives}

The research material has grown out of continuous fieldwork in Malawi. The work is rooted in ethnographic methodology, with a sensory perspective. The sensory apparatus is crucial to how I perceive and understand conversations, dance classes, drum classes, places, smells, sounds and the general atmosphere of the actual space (Pink, 2009).

\section{The researcher's voice}

I am a Norwegian citizen, born and raised in Norway, with all the privileges of education, travelling and financial security that might give, and as an adult I also got a Malawian family. As part of a Norwegian/Malawian family, as a musician and music

\footnotetext{
${ }^{1}$ Modern in this context means two things: modern dancing refers to dances in African and global pop culture. Modern, when referring to a modern society, modern living, etc., connotes urban, educated, technology-using, knowledge- and globally oriented.

${ }^{2}$ http://www.music-crossroads.net/about/ (Access 20.05.2019)
} 
researcher, I have been staying in Malawi for many periods, usually of between 1 and 3 months, since 2014. When I am in Malawi, I typically spend time at Music Crossroads, both giving and participating in workshops, taking part in Dumas dance classes, contributing to the musical education of the dancers, and taking drum lessons with Duma or one of his students. My position as a Norwegian university-educated person, mastering a rare instrument in Malawi (the accordion), my position is also worth looking at ethically. As the writer of this article, how am I supporting the colonising powers of Western academic traditions? To this, I must say: possibly on many levels, an important aspect of the research. I also see it as a duty to contribute with my kind of knowledge ${ }^{3}$. I can merely hope, since this has been a process where Duma and Mathews Mfune (the director of MCM), as well as many Malawian friends and colleagues, have contributed by being readers, significant research participants, discussion partners and consultants, that my writings are more of a starting point of discussing and developing these issues, rather than a final answer to the needs of research on Malawian traditional expressions.

\section{Using the interview quotes as untamed stories}

The material from the interview with Duma is presented as fragments, written in italics. Some of the fragments are quotations, and some are embedded in the text. I have let the stories from Duma be what Anna-Lena Østern and Sunniva Hovde call untamed (2019), as I have used fragments from Duma's stories not to look for coherence, but rather to examine the complexity contained in the utterances on dance education. Luc Herman \& Bart Vervaeck (2005) write about postmodern stories as "les savages narratives" (untamed stories), with patchworks as juxtapositions of disjunctive stories, and not a continuous pattern (Østern \& Hovde, 2019).

\section{Doing fieldwork as an ethnomusicologist}

When doing fieldwork, I am used to noting my own process as well as what is going on around me: how it feels, how the teacher(s) are interacting with me or the rest of the participants, how it smells, how it is part of someone's everyday life, and how people interact and relate to the arts. It is necessary to use my senses in a broad way. Nic Beech and Stephen Broad (2018, p. 5) phrase it in this way: "fieldwork provides the route through which the researcher becomes immersed in the music and meaning of a culture." Sensory ethnography has been re-introduced as a methodology to acknowledge the sensory part of fieldwork, and how much information it actually gives us (Pink, 2009). When you do not feel indigenous in the culture you are operating in, your sensory apparatus can be on an intense perception-volume, in order to

\footnotetext{
${ }^{3}$ The establishment of educational programmes like "African Musicology" and "Indigenous knowledge systems and practices" at institutions like Malawian University demands more knowledge and research on Malawian music and dance within knowledge systems that can communicate with other academic knowledge systems around the world, and I hope I can contribute to these discourses.
} 


\section{S. S. Hovde}

perceive and receive all the information you might need to understand the situation you are in. That has at least been the situation for me, in many situations: trying to absorb all the details in my drum teacher's hands, his jokes, the movements in the dance, the interaction between the dance, the drums and the students, as well as other people's musical, physical or social commenting.

For some time, I had Duma as a drum teacher. He would show me a few drum patterns, but the rest I would learn with the dance troupe Hear Us Children as he believed you cannot learn to play drums alone. He emphasised that I had to have confidence that the drum did what I wanted it to, as well as having the selfconfidence to play independently. I followed Duma closely through many observations when Hear Us Children was practicing outside in the same area; we had some workshops together on how to teach traditional dance, many informal conversations, and observations within and outside of the MCM camp. I had one formal interview with Duma, in March 2018, in his classroom, while the dance troupe was practicing outside. The interview was scheduled with him, and when I planned it, I asked specifically if I could perform the interview with the purpose of writing this paper.

\section{The analysis of ethnographic data in this study}

The ethnographic data are analysed through a post-human positioning, utilising perspectives on intra-action and agential realism from Karen Barad (2014) and disagreement-tracing (Latour, 2005) in a post-colonial context (Hovde, 2012). Through these perspectives, I have wanted to destabilise dichotomies like modern/traditional, city/village, individual/community, Malawian/non-Malawian, and African/ European(American) that easily present themselves as available from a global hierarchical understanding, but whose contexts are connected to colonising systems and terms. The intra-action way of thinking corresponds well with the intra-relational concept of ubuntu, as the relational rationality weaves both future, past, present, nature and culture together with mutual dependency on each other (Murove, 2012).

A position within Barad's agential realism (2014) implies the use of human and non-human performative agents of importance for the learning processes (Østern \& Hovde, 2019). They are entwined and intra-acting, like the relations in a community. In Duma's stories, uMunthu is a strong performative agent, but so also are globalisation, modernisation, love, education and tradition. The entanglements are analysed by looking for traces of conflicts between performative agents and congestions of energy, indicating many performative agents being active. When Duma relates love to a number of other aspects, or when he talks about respect in a variety of forms, it gives energy to the performative agents (love, or respect/uMunthu), and they are what Gilles Deleuze would call the starting point of a line of flight (Deleuze, 2005). Analysis has also been fuelled by me noting that Duma was pointing out something, like storytelling, in an intense way, affected by the importance of it, even though I was not left with a large amount of material connected to storytelling. I also understood storytelling as important, because it has such a crucial value in Malawian relations. 
These sparks of energy and traces of conflict as an analytical tool have contributed to the embodiment and intra-acting of agents with time-space, materiality, sociality and cultural expressions. Barad (2014) emphasises that the colonising logic implies either eliminating, or dominating "what it takes to be the other, the non-I" (Barad, 2014, p. 169). To contribute to destabilising these structures has been one motivational factor, and I hope that the focus on the material, on the local knowledge and the local pedagogical perspectives can fuel this process.

When, for analytical purposes, I present a dichotomy, at the same time I cut it together in a diffractive process (Barad, 2014). The material can be split up, to then be put together differently. In doing this, I can see them as variations of each other, not oppositions. Throughout the analytical process these performative agents stood out:

- uMunthu

- (traces of) intra-actions, where historical, financial, geographical, cultural and/or hierarchical concepts of modern, traditional, educated, urban, rural, Malawian, non-Malawian, Western, are present

- (traces of) intra-actions, where social agents in the culture - community, tribes, gender, family, are present

- Duma's positioning as an artist and teacher

These performative agents relate to each other on different levels and in different entanglements, and it is these entanglements/relations that I have been examining.

\section{Results: Entanglements of uMunthu and other performative agents in the teaching pedagogy of Duma}

Here, I repeat the research question guiding this article:

With which terms, artistic and pedagogical concepts does fohn Duma express the educational entanglements in the teaching of traditional dance in Hear Us Children, and how is uMunthu a part of this?

The identified entanglements most present in Duma's educational perspectives, as I see it, are:

- uMunthu, the community and the inter-relational dance practices

- Love: dancing to trust yourself

- Tribal-modernized-urban-traditional-Western dynamics

- Storytelling: physical, social and historical movements and sense of community

In the following sections I will present the entanglements I have produced through the analysis. As I do this, I will also include theoretical perspectives.

uMunthu, the community and intra-relational dance practice

uMunthu, as explained by Duma, is related to three things: "You do things at the right time, at the right place to whomever." He then explains that uMunthu has to do with 
the fact that your actions are always affecting someone, somewhere, at some time. "If I don't respect your time or your background I am not doing good. The kids have to respect their teacher, themselves and me, their family, neighbours and fellow kids." uMunthu in this sense is connected to being part of the community and for the child to be growing into a human being as part of something and not being an animal in the wild. In addition, Duma states: "uMunthu is also about bringing the youth together".

As the community needs educated children, he keeps a vigilant eye on all the students and makes sure that they "study extra hard":

Dance is just a tool to grip the students. My teaching is not only about dancing; the dancing is just a tool to engage them and bring them together: a good tool, but just a tool. (...) I am not training them for the programmes, actually, I am always training to teach them (making a circle in the air) "the whole", for a programme, and to counsel them. They should work extra hard in school.

He creates a space where the outlines of formal and informal education are challenged and broken down (Bracken, 2014). The dance-activity becomes an opportunity to create a relationship between the community, the school, the dance, the student and the family. Community music researcher Jillian Bracken (2014) states that community music also provides opportunities for extra musical benefits: in the case of MCM and Hear Us Children, entrepreneurship and leadership, as these are greatly needed qualities in a country where there extensive unemployment.

Duma's core aim for the group is that they are as good artistically as possible. The artistic ambition is part of a love-relation, as they work for the same artistic expressions together. His focus on both art as a tool to "grab the students" and his profound interest in traditional dance practices are not conflicts of interest.

Mabingo (2015) identifies music to be a learning tool, and so does Duma. When the children do not have drums to accompany them, they sing the rhythms: "Then we start singing. They're singing many times. Many times. Then dancing and singing together". They let the music be

(...) an aspect that invokes the body's agency in understanding movement. Students play music to understand dance from a standpoint of makers and producers of rhythmic frameworks that inform and frame dance. (Mabingo, 2015, p. 137)

As music and dance can be understood through each other, both Duma and Mabingo (2015) comment on the relational aspect, which you learn as: "(...) Ugandan dances are grounded in relational interdependence of performers" (Mabingo, 2015, p. 39). The norms are taught not in terms of solitary individuals, but as a community. It is through the community that you learn the dance, how to gain self-esteem, and where to train to be uniform/precise or responsible leaders. When they intra-act, applying Barad's (2014) term, together their relations with each other, with each other's families, communities and identities overlap and change all the relationships from within. They depend on one another as their relationship is not something between them, but the relationship is in them: they are both themselves and the relationship. 
Miriam Giguere emphasises the humanity in community dance, as follows: "It's about who these dancers are and what dance can do for them [...]" (2017, p. 3). This is significant for the way Duma is teaching. Giguere also points to the challenges of dealing with individuals in a setting where you have the community's wellbeing foremost in mind, which Duma addresses when he mentions how some families persuade their daughters to get married at a young age. Because of a lack of financial resources and within a cultural tradition, the families want the girls to marry, as after a marriage, the girls are no longer the responsibility of the parents, but the husband's. These girls are the high-risk population in school drop-outs and unemployment. The community, here represented by Duma, wants as many educated children as possible, while the family might have other priorities.

\section{Love: Dancing to trust yourself}

Duma emphasises the importance of love, and that if the children do not love him or his plans, in the sense that they know he truly cares for them, he has failed as a teacher. His focus on trust from the students' side is deep and remarkable. The Finnish dance researcher Isto Turpeinen (2015) also emphasises love as the basis of his own dance teaching. Turpeinen discusses how "pedagogical love" is related to agape, unconditional respect, as well as the pedagogue Paulo Freire's concept of dialogical education being related to love as a "crucial medium facing a genuine human existence" (Turpeinen, 2015, p. 97). Turpeinen explains "pedagogical love" as an altruistic relationship with the other, including his/her potentiality, actuality, character, aspirations and limitations. This is recognisable in Duma's philosophy as he explains love as related to trust, to be part of a community. He talks about how love and uMunthu have to do with growing within society and the community through being together, caring for each other, and leading each other:

From my side, I know that now (if they care for each other) they are growing up. I should give them leadership. To teach dancing is to teach respect and leadership, too. (...) It is about bringing them together, and uMunthu is the basis of being together. And in the dance, there is friendship, uMunthu.

Love-trust is an entanglement, something Duma expects and somehow demands from his students. They should give it to each other, to him and to their families. He also emphasises the importance of self-love-trust, of trusting your own way of uMunthu, and respecting yourself for who you are in the community. These are not contradictions, but co-existence, forming the community.

Duma first mentioned the concept of love and trust through discussing the hipmovements of some of the children in the troupe. There would be great variations in how they did a particular hip-movement, and I knew he appreciated that each child would have their own style: "That is because they have to do it from the bottom of their heart, in their own way. (...) But it is a good thing that they do it their own way, still similar. It is important. It is part of their confidence. He acknowledges the different bodies the 
children have, and that they learn that all bodies behave differently and give different expressions: their bodies should not have anything forced upon them.

The self-confidence you get through being part of a communal practice stands out as both a result of and a means to dancing, if it comes from the student and is not forced. Duma points out that the children/students also learn self-confidence through the training for the dance, as they will criticise each other if they are not doing the movements correctly, or if their facial expressions are not the right ones:

And in dance, the way I know that this one has got self-confidence is he knows where to start or to teach his or her friends, with respect. (...) You don't need to prove yourself. I see it even if their backs are turned to me.

Duma explains that self-confidence means to be on your own, to take decisions on your own, and that if you do not have self-confidence you are not a man or a woman. He points at me and tells me: "You left Norway because you have self-confidence on your own. You are on your own". When I reply that I think maybe it had to do with curiosity in my case, he says: "How can you be curious about other things if you are not confident in yourself?"

\section{The tribal-modernized-urban-traditional-Western entanglement}

While many of the dances are unproblematic to dance according to tribe, initiation dances opens a door to a cultural and artistic challenge. Duma would like to teach both boys and girls the full initiation dances, but it is not possible as they then would be formally initiated into the actual tribe, and the children come from different tribes. Some have more tribal awareness than others, and in the city tribes tend to be less important, but not for all families. As a result of this, the dances they learn are not learned as part of an initiation ceremony, but just as dance. Duma emphasises that these learners are young children and not yet ready to learn the full version of an initiation dance, like the chisambat. (a female version of the male-oriented Gule Wamkulo $^{5}$. The transfer from a village-based, informal, community-oriented dance practice meets the formality of MCM, corresponding more to modern expectations. If he had been teaching in the village, it would not matter if the children were young: they would learn it, and it would be part of their games, until they were considered old enough for initiation ${ }^{6}$.

\footnotetext{
${ }^{4}$ There can be many variations of the chisamba, and the information I have about the dance has been obtained from various women within the Chewa tribe in the Lilongwe/Ntchisi area, who would have gone through the initiation. In other Chewa districts the dance might have a different structure or dramaturgical framework, even though the main events would be similar. Here is a link to a chisamba program with junior students at Hear us Children in 2015: https://vimeo. com/338988916/9d2ccb274e

${ }^{5}$ Gule Wamkulu: https://www.youtube.com/watch?v=H30wcV6-wbw

${ }^{6} \mathrm{~A}$ problem in Malawi is that girls especially are considered old enough to be initiated at a very young age. Child marriage has been a common problem, and even though laws can prevent such a
} 
Duma refers to a similar issue about understanding the culture and the sociocultural context of the dances/music:

When the kids are in school, they are in town, of course. In the holidays the parents still keep them here, not going to their respective villages, to see their culture, their land and their heritage. It affects the indigenous knowledge a lot, because here we don't have real traditional dances originating from home, but in their villages they can see the real traditions, so when they are here they just see the surface and not the base.

Even though Duma did not train as a dancer as a child, he says he knew the steps,; his eyes and his body knew all of it, the muscles just had to be used to the movements. Mabingo uses the term "communal apprenticeship" (Mabingo, 2015) as a "methodical process that engages the participants in norms of creativity and practices not as isolated individuals but as a community" (Mabingo, 2015, p. 136).

Duma emphasises the importance of tradition as the core of the dance troupe, and while he plays down his tribalism, he emphasises the local/village sound while talking about how he builds up the repertoire as something supporting the dance, even though it can be played with: "(...) in the beginning, it would be very much local sound. It would be like straight from the village. But for market purposes I can put some dynamics and variations to add some flavour". In this fragment he shows us a glimpse of an entanglement of purposes: village-programme-modern-local-market-variations.

\section{Storytelling: Physical, social and historical movements and sense of community}

In Duma's practice the beginnings are the children's stories about themselves and about the dances. Duma's storytelling of the dances, as Mabingo (2015) also indicates, is an important part of putting the movements into a context where they can be felt, understood and done. The stories are ways of preparing the movements and the artistic performance ${ }^{7}$. When the children succeed, he adds flavours:

I could add beats on top and let them be dynamics for the dancers and for the drummers. So, they would see me play as well. Hear my playing not just for showing them what to play, but to be part of my playing. Adding flavour. But in the beginning, it would be very much a local sound. It would be like straight from the village. But for market purposes I can put some dynamics and variations to add some flavour.

In playing for them, and developing the rhythms, adding the flavours, he also shows them how he is as a performer, and how it sounds artistically when he plays. In Duma's educational philosophy, the teacher is a performer. He never stops performing. He

marriage, it is not uncommon that it still happens. This historical trace is of course also part of the entanglement.

${ }^{7}$ I observed a group of students changing the stories for one military dance, beni, containing movements imitating shooting, marching and scouting, originating from the two World Wars. The students were replacing the movements that referred to old fashioned guns with movements from spy-movies and gangster-shooting with handguns. I asked them if they were dancing beni, and they responded that they were, but laughing and telling me this was the ghetto-beni, not the traditional one. They made their beni story. 
mocks them, or himself, to make them laugh and he changes his emotions to show them who he is, and guides them. He performs as an artist and he is performing as a teacher.

When he teaches the younger children or the new beginners, he tells them the stories of the dances, and when he performs the dance and shows them the art, not just the steps, but the real thing, he emphasises the importance of showing and telling as an artist, because they should feel the dance - inside. If not, they cannot love it, and they cannot perform it properly. His focus on the children's competence in telling a story, but also their experiences of art, is an important contribution, as it is a performative pedagogical entrance: it includes him as an artist teacher and shows the importance of meaningful art experiences for children.

When someone struggles with movements, he often turns to games, jokes and already familiar movements as educational tools to activate already established competence. It is used to "inaugurate learners into (...) practicalities of dance" (Mabingo, 2015, p. 138).

If they don't manage I use my hands and move them (the children's body parts) with my body. Very few need this. (...) I would ask that girl who didn't manage - she was very youngto greet me. If you greet someone, you do the exact, perfect movement. It is important to make the movements familiar to them in ways they know.

The stories he tells when he is teaching, the stories he tells about himself as a teacher-artist when he is teaching and performing, and the stories he creates when he wants to put the knowledge together for them, to learn more easily, these are also part of a Malawian storyteller-tradition. Knowledge is passed through oral words and where you actually are your stories when you dance, present yourself, or teach.

Figure 1 is a visualization of the entanglements presented in the article. They fold in and out of each other, twist, share, repel and connect each other through shared performative agents, time, materiality and space. As the words share spaces, some places, they share a thread somewhere else, and the performative agents are truly entwined and intra-acting.

\section{Discussion: John Duma's educational entanglements in the teaching of traditional dance in Malawi with uMunthu as a central performative agent}

uMunthu, visualized in Figure 1 with the grey and blue thread, turned out through the analysis to be both a performative agent in relation to other agents, like colonialism or modernity, and also a concept consisting of other performative agents interweaving their relations again and again. When the dancers train their leadership, their self-confidence and their respect for each other and themselves through the community of other dancers, it is an act of uMunthu. uMunthu, on a more overarching level, can be put together with modernity on the issues of individual freedom of expression and the community's need. Duma shows how these operate together when he talks about the aesthetics of hip movement and the need for the movements not to be uniform, but to come from the bottom of the student's heart. It is worth 


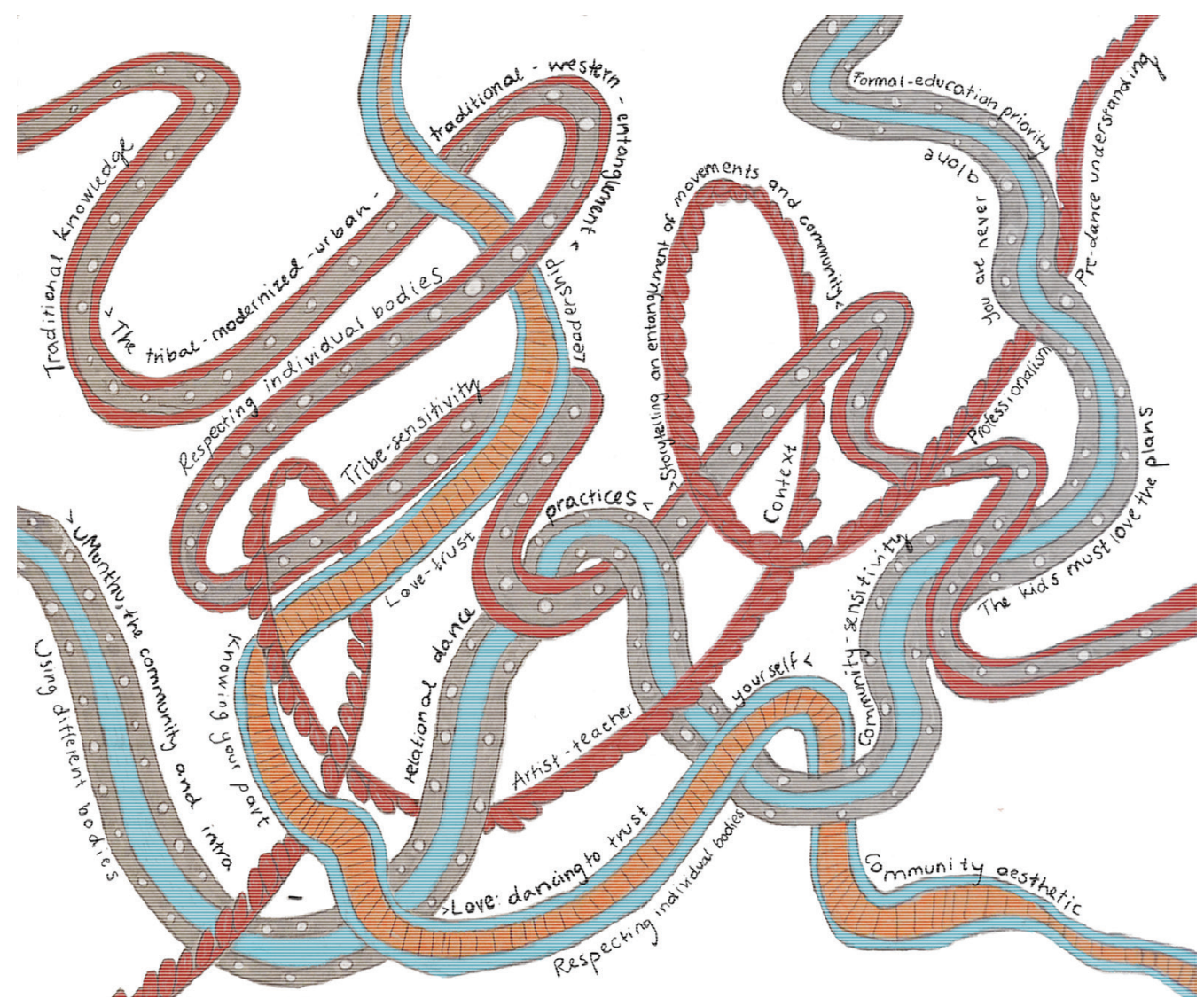

Figure 1. Visualization of the identified entanglements most present in Duma's educational perspectives. Design: Matilda Ståhl.

mentioning that the reason they can operate together is that the individuals accept, acknowledge and understand the core of the system. If you do not comprehend the core system, you will not know your part, because your part is unconditionally linked to the community's structural concept. This differs from what Mabingo refers to when native intellectuals are being pressed into Western/modern ways of learning: "(...) introduced through European colonialism and entrenched by the postcolonial education regimes" (Mabingo, 2015, p. 132).

On the other hand, when it comes to the initiation dances (the red and grey thread in Figure 1), he says "what do you think the institution would say if we did that!" (in other words, if we taught the whole initiation rite), and this might be seen as strong Western/modern agents connecting time through colonialism, postcolonial development values and new colonial practices in globalised music. They are cut together in Duma's practice, as he emphasises traditional knowledge, under-emphasise tribal knowledge and considers the values of the urban-modern-traditional space he is operating in. 
uMunthu informs the core of Duma's teaching practice, but is also developed through the same practice. Modern perspectives allow Duma to soften the gendered dances, and invite the girls to dance what is traditionally seen as a boys' dance, justified with "we always want the best dancers to dance": a practice of uMunthu where everyone comes with their strengths to the better good of the community. This is not controversial, but it is not common either. The gender roles at the core of traditional culture in Malawi are not equal when it comes to decision making. The balance between a more modern way of treating gender, in line with how young people today look at gender roles, and maintaining traditional knowledge, commonly being gendered is an aspect he does not talk much about. Talking might not be, though, the only way of changing. His educational practice does, as I see it, contributing to more generous gender roles.

Duma speaks a lot about love (the yellow-red thread in Figure 1), and it is evident in both artistic and social format. To work artistically for the same goal and to perform as a community is love, according to Duma. When they put in their hard work, strengths and self-confidence for the benefit of the others, they also show love, as they also do when they criticise each other respectfully. The goals are the same: to dance as well as possible. In this process, the self-respect for who they are in the community is strengthened, because they are themselves and their relationships at the same time, and if they show love, trust and respect for the relationship, they also show it to themselves.

The stories are central in Duma's pedagogical perspective, as educational and artistic tools, as well as a performative tool, as his role as a storyteller, educator and dancer shapes the pedagogical practices he outlines. In Figure 1 this is visualised with the red thread. He does not problematise this, and rather expresses it through stating that this is what he can teach hem. He is not trying to be neutral, but rather perform his own story, gender and tribal connection and acknowledge them as performative agents in his educational perspectives.

\section{Conclusion: uMunthu, the artist-teacher, love, sensitivity and modernisation}

In the discussion and analysis of this material there are performative agents that might seem to be dichotomies. However, as a conclusion, I suggest these performative agents are not seen as dichtotomies. They are merely continuously performative in entanglements, where the whole spectre is operative and performative in producing the pedagogical practice. There are traditional practices, body movements, modernised ideals, urban/rural cultures, as well as a relational difference in needs in the family, community and the student. Entanglements of different interests must be handled with care, and with cultural sensitivity, with love and communication. The entanglement of uMunthu, formal education and modernisation is also worth looking at, as the practice at the side of formal education is very important in order to support and motivate the students' formal education, even though this might not benefit the traditional practices of the community. Formal or not, Hear Us Children is arts education, 
and the children will benefit form it, if not formally, then very much informally, by getting to know themselves through traditional expressions, though their lifestyle might be a modern urban Malawian lifestyle. The concept of uMunthu is important in Malawian arts education, in redefining how traditional expressions can contribute to the community through supporting education, but also in destabilising colonising arts practices and education in a society that has been, and still is, under great colonising pressure. However, the concept can also contribute to decolonising the pedagogies in other places, as in Norway, as well as empowering local, bodily art practices, embedded in deep traditions. In strengthening local concepts such as uMunthu and the artistic and pedagogical terms used in different Malawian traditional expressions, this will also contribute to the decolonising process of Malawian artistic practices.

Duma performs his pedagogies as an artist, within entanglements of uMunthumodern-local-tribal-Malawian-love, contributing to the building of trust, as an artistic authority. He performs as himself, as the person he is today. The dance is the life of a person, the daily life, Duma says.

\section{A critical view of the study - and suggestions for further research}

This study is an investigation and a discussion of the pedagogical perspectives in John Duma's practice of traditional dance education in Area 23, Lilongwe, Malawi. The study potentially has blindspots caused by my, the author's economic, educational and national privileges, and there is potential cultural/knowledge appropriation happening, all the time that I am a married Malawian, and not Malawian-born. I have done my best in this regard, but this also gives space for exoticism and an overly uncritical way of analysing the material. In this study, though, the aim has not been to look critically at the educational perspectives. Being non-indigenous, I do not consider that to be my role, but I encourage and hope for this to come from Malawian contributors in the field, as it is healthy in a discourse, and needed to develop the field of knowledge. I see some possibly interesting roads to walk down for further research, one of them being how the students relate to the dynamics in gender roles in dance in Malawi, both traditional and modern. There is a wide variety of sexualisation in Malawi, both between genders, and within, dependent on class, geography, tribe and education. Another path is to follow the relation between humans and traditional music/dance, how people perceive a young traditional dancer and how traditional expressions are meaningful in peoples' lives. There is also a need to further formalise the pedagogical perspectives on dance learning at Music Crossroads Malawi, as the institution also wants to formalise the dance education that until now has been informal. The relationship between particular traditional dances, like Gule Wankulu, young performers and the modern society is another arts-based research-path I find intriguing. Finally, I want to mention that I find it particularly interesting how the young traditional dancers at Music Crossroads Malawi, who also perform modern dances, mix the traditions, and how modern and traditional concepts are even less dichotomous than they might have been perceived in this article, when it comes to practical dance routines and music mixing. 


\section{S. S. Hovde}

\section{Author biography}

Sunniva Skjøstad Hovde ( $\mathrm{PhD}$ in Ethnomusicology) is a researcher and an artist with an interest in local/ global performative arts practices and the artistic/educational potential in diversity, improvisation, decolonizing and embodied knowledge. Her exploration of artistic/post qualitative perspectives/entrances in the attempt of outlining tools to analyze complexities goes deep into performative artistic expressions as well as theoretical work. Her field includes music and at times dance, as this goes together many places in the world. She works at the moment as Associate Professor in Arts Education, at the Department for Teacher Education Norwegian University of Science and technology.

\section{References}

Akinola, A. O., \& Uzodike, U. O. (2018). Ubuntu and the quest for conflict resolution in Africa. Fournal of Black Studies, 49(2), 91-113. https://doi.org/10.1177/0021934717736186

Barad, K. (2014). Diffracting diffraction: Cutting together-apart. Parallax, 20(3), 168-187. https://doi.org/10. 1080/13534645.2014.927623

Beech, N., \& Broad, S. (2018). Ethnomusicology. In C. Cassell, A. Cunliffe, \& G. Grandy (Eds.), The $S A G E$ handbook of qualitative business and management research methods: Methods and challenges (pp. 398-413). London: SAGE. https://doi.org/10.4135/9781526430236

Bracken, J. L. (2014). Community music. In W. F. Thompson (Ed), Music in the social and behavioral sciences: An Encyclopedia Vol. 1, (pp. 215-220). Los Angeles: Sage Publication.

Deleuze, G. (2005). Tusind plateauer: kapitalisme og skizofreni. [A Thousand Plateaus: Capitalism and Schizophrenia] København: Det Kongelige Danske Kunstakademis Billedkunstskoler.

Emielu, A. (2018). Tradition, innovations, and modernity in the music of the Edo of Nigeria: Toward a theory of progressive traditionalism. Ethnomusicology, 62(2), 206-229.

Giguere, M. (2017). Introduction to the special issue: Community dance practices. Dance Education in Practice, 3(2), 3. https://doi.org/10.1080/23734833.2017.1310527

Herman, L., \& Vervaeck, B. (2005). Handbook of narrative analysis. Lincoln, Nebraska: University of Nebraska Press.

Hoffmann, N., \& Metz, T. (2017). What can the capabilities approach learn from an Ubuntu ethic? A relational approach to development theory. World Development, 97, 153-164. https://doi.org/10.1016/j. worlddev.2017.04.010

Hovde, S. S. (2012). Global musicking; Innvandring og den farlige forskjelligheten. [Global Musicing: Immigration and the Dangerous Difference] (Dissertation). Trondheim: NTNU Norwegian University of Science and Technology.

Kayira, J. (2015). (Re)creating Spaces for "uMunthu": Postcolonial theory and environmental education in Southern Africa. Environmental Education Research, 21(1), 106-128.

Latour, B. (2005). En ny sociologi for et nyt samfund. [A new sociology for a new society] (C. B. Østergaard, Trans.). København: Akademisk Forlag.

Mabingo, A. (2015). Decolonizing dance pedagogy; Application of pedagogies of Ugandan traditional dances in formal dance education. Fournal of Dance Education, 15: 4, 131-141. https://doi.org/10.1080/1529082 4.2015 .1023953

Matthews, S. (2017). Colonised minds? Post-development theory and the desirability of development in Africa. Third World Quarterly, 38(12), 1-14.

Mfutso-Bengo, J., \& Masiye, F. (2011). Toward an African Ubuntuology/uMunthuology bioethics in Malawi in the context of globalization. In C. Myser (Ed) Bioethics around the globe. New York. Oxford UP. https://doi. org/10.1093/acprof:osobl/9780195386097.003.0010

Murove, M. F. (2012). Ubuntu. Diogenes, 59(3-4), 36-47. https://doi.org/10.1177/0392192113493737

Pink, S. (2009). Doing sensory ethnography. London: SAGE. https://doi.org/10.4135/9781446249383

Schreiber, R., \& Tomm-Bonde, L. (2015). Ubuntu and constructivist grounded theory: an African methodology package. Fournal of Research in Nursing, 20(8), 655-664. https://doi.org/10.1177/1744987115619207

Turpeinen, I. (2015). Dialogue and "pedagogical love". Atmosphere and reflexivity in dance. In C. S. Nielsen \& S. Burridge (Eds.), Dance education around the world: Perspectives on dance, young people and change (pp. 95-99). ProQuest Ebook Central: Routledge. https://ebookcentral.proquest.com/lib/ntnu/detail. action?docID $=2011283$. 
United Nations. (n.d.). World population prospects 2017 [Statistics]. Retrieved from https://population.un.org/wpp/ 02-02-2019 Skriv ut denne forkortelsen

Tutu, D. (2010). UBUNTU. Amnesty International, 37, 23. Retrieved from https://search.proquest.com/ docview $/ 854327631$ ? accountid $=12870$

UNESCO (2009). The Gule Wamkulu. https://vimeo.com/338981325/463ed2cc3c.

Østern, A. L. \& Hovde, S. S. (2019). Untamed stories told by artfully creative artists in Malawi and Norway. In A-L, Østern \& K.N. Knudsen (Eds.), Performative approaches in arts education (pp. 168-190). London. Routledge. 